\title{
ANALISA PELAKSAAN RETENSI DOKUMEN REKAM MEDIS DI RSU MUHAMMADIYAH PONOROGO
}

\author{
EVINIA BETRI \\ E-mail: Eviniabetri01@gmail.com \\ Program Studi D-Iii Rekam Medis Dan Informasi Kesehatan Stikes Buana Husada Ponorogo
}

\begin{abstract}
ABSTRAK
Pelaksanaan dokumen rekam medis berpedoman pada standar operasional prosedur tentang penyimpanan dokumen rekam medis di ruang penyimpanan. Ruang penyimpanan (filling) merupakan tempat dokumen rekam medis rawat jalan, rawat inap dan gawat darurat disimpan dengan metode tertentu dan pelaksanaan retensi rekam medis. presentase dalam 5 tahun terkahir belum dilaksanakan retensi sebesar 100\% dokumen rekam medis di RSU Muhammadiyah Ponorogo. Jenis penelitian ini adalah deskriptif. Tehnik pengumpulan data dengan cara wawancara, observasi dan meminta data petugas rekam medis. Sampel data pada pneelitian ini adalah 3 petugas filling di RSU Muhamamdiyah Ponorogo. Tehnik yang dilakukan tehnik sampling jenuh. Hasil penelitian yang didapatkan bahwa pada pelaksanaan retensi petugas retensi melaksanakan retensi sebanyak 100-150 dokumen rekam medis dalam waktu 1 (satu) hari dan dalam satu (1) bulan petugas melaksanakan retensi sebanyak 3000 dokumen rekam medis, terdapat 100 dokumen rekam medis rusak dan tidak bisa terbaca. hal tersebut menyulitkan petugas pada saat pelaksanaan retensi dokumen rekam medis. Saran petugas pada saat pelaksanaan retensi dokumen rekam medis terlebih dahulu memisahkan dokumen rekam medis yang rusak dan tidak rusak dan dilihat tanggal berobat ababila tidak bisa dibaca petugas melihat langsung di komputer di data pasien.
\end{abstract}

\section{Kata kunci: Pelaksanaan Retensi, Dokumen Rekam Medis}

\section{PENDAHULUAN}

Rumah sakit adalah institusi
pelayanan kesehatan yang
menyelenggarakan pelayanan kesehatan
perorangan secara paripurna yang
menyediakan pelayanan rawat inap,
rawat jalan, dan gawat darurat. Rumah
sakit sebagai institusi yang bergerak di
bidang pelayanan kesehatan yang harus
senantiasa memberikan kepuasan
kepada setiap pasien dengan
meningkatkan mutu dalam segala
pelayanannya, dengan memberikan
pelayanan kuratif dan rehabilitative
(Permenkes No 56 tahun 2014).
Rekam Medis adalah berkas yang
berisi catatan dan dokumen tentang
identitas pasien, pemeriksaan,
pengobatan, tindakan dan pelayanan lain
kepada pasien pada fasilitas pelayanan

kesehatan (Permenkes RI Nomor 55 tahun 2013. Salah satu bagian rumah sakit yang menunjang dalam pelayanan rekam medis pasien adalah ruang penyimpanan (filling) dimana dokumen rekam medis baik rawat jalan, rawat inap maupun gawat darurat disimpan karena rekam medis pasien bersifat rahasia dan mempunyai aspek hukum maka keamanan fisik menjadi tanggung jawab rumah sakit, sedangkan aspek isi dari rekam medis merupakan milik pasien. Pelaksanaan penyimpanan dokumen rekam medis berpedoman pada standar operasional prosedur tentang penyimpanan dokumen rekam medis di ruang penyimpanan. Ruang penyimpanan (filling) merupakan tempat dokumen rekam medis rawat jalan, 
rawat inap dan gawat darurat disimpan dengan metode tertentu dan pelaksanaan retensi rekam medis.

Retensi adalah proses kegiatan memilih dokumen rekam medis untuk memisahkan dokumen rekam medis aktif ke in aktif sesuai jangka waktu penyimpanan dokumen rekam medis. Dalam pelaksanaan retensi petugas melihat jadwal retensi arsip (JRA) sebagai pedoman untuk menentukan jangka waktu penyimpanan dokumen rekam medis. Dokumen rekam medis di simpan sekurang-kurangya 5 tahun dilihat dari perakhir pasien berobat. Pelaksanaan retensi bisa dilakukan setiap hari, bulanan, maupun tahunan. Hal ini bertujuan untuk mengurangi jumlah dokumen rekam medis yang ada dan untuk menghindari bertambahnya dokumen rekam medis setiap harinya maka perlu adanya retensi dokumen rekam medis.

Pelaksanan retensi dengan cara memilih dokumen rekam medis yang memiliki nilai guna seperti resume, informed consent, lembar operasi, lembar kematian, lembar identitas bayi. Lembar yang akan memiliki nilai guna akan disimpan dan di scanner sedangkan dokumen rekam medis yang tidak memiliki nilai guna ditumpuk di dokumen rekam medis in aktif kemudian akan di lakukan pemusnahan.

Berdasarkan survei awal yang di lakukan pada tanggal 4 januari 2019 di Unit Rekam Medis RSU Muhammadiyah Ponorogo melalui wawancara petugas rekam medis bahwa RSU Muhammadiyah sudah melakukan retensi pada tahun 2014, pada tahun 2019 ini petugas akan melaksanankan retensi terdapat kendala pada saat melakukan retensi yaitu kurangnya sumber daya manusia, waktu dan banyaknya dokumen rekam medis yang belum di retensi dan petugas kesulitan bagaimana cara agar retensi dilaksanakan dengan baik sesuai dengan SOP rumah sakit petugas sebelum nya memiliki tugas pokok yaitu petugas mengambilan dokumen rekam medis yang di ruang filling untuk di antar ke poli-poli hal tersebut menyulitkan petugas untuk pelaksanan retensi dokuemen rekam medis.

RSU Muhammadiyah Ponorogo sudah memiliki SOP di mana di dalam SOP tidak di cantumkan JRA (jadwal retensi arsip) menyebabkan petugas menunda-nunda retensi dokumen rekam medis, hal tersebut menyebabkan dampak yang tidak baik sehingga dokumen rekam medis menumpuk sangat banyak di ruang filling, presentase dalam 5 tahun terkahir belum dilaksanakan retensi sebesar $100 \%$ sedangkan rata-rata pasien perhari berkunjung di RSU Muhammadiyah ponorogo mencapai 150 pasien rawat inap maupun rawat jalan perhari jika penerimaan pasien 24 jam maka ruang filling juga harus buka 24 jam.

Tujuan penelitian ini adalah Mengidentifikasi Pelaksanaan Retensi Dokumen Rekam Medis di RSU Muhammadiyah Ponorogo

\section{METODE PENELITIAN}

Penelitian ini menggunakan analisis deskriptif, yaitu penelitian yang mengarahkan pada sekumpulan objek yang memiliki tujuan untuk memberikan gambaran atau mendiskripsikan suatu keadaan tertentu (Notoadmodjo, 2010). Dengan penelitian yang dilakukan untuk mendeskripsikan atau menguraikan tentang pelaksanaan retensi dokumen rekam medis. Metode pengambilan data yang digunakan dalam penelitian ini dengan cara observasi, wawancara dan dengan meminta data di bagian rekam medis.

Pendekatan yang di gunakan adalah cross sectional (potong silang) atau seksional silang, variabel sebab akibat kasus yang terjadi pada objek penelitian di ukur dan di kumpulkan dalam waktu yang bersamaan (simultan. Pelaksanan penelitian pada bulan juni 2019 di RSU Muhammadiyah Ponorogo Populasi pada penelitian ini adalah 3 petugas rekam medis di bagian filling dan kepala instalasi rekam medis, SOP retensi dokumen rekam medis, alat-alat retensi. pengumoulan data dengan wawancara 


\section{Jurnal Delima Harapan 2020}

dan observasi, kemudian dianalisis sesui dengan teori.

\section{HASIL DAN PEMBAHASAN}

1. Mengidentifikasi pelaksanaan retensi dokumen rekam medis

Berdasarkan hasil wawancara yang dilakukan peneliti pada petugas rekam medis terkait tinjauan pelaksanaan retensi dokumen rekam medis bahwa RSU Muhammadiyah Ponorogo melaksanakan retensi pada tahun 2014. Saat ini rumah sakit RSU Muhammadiyah Ponorogo akan melaksanakan retensi dokumen rekam medis. berdasarkan wawancara jumlah dokumen rekam medis belum direntensi tahun 20152019 di RSU Muhammadiyah Ponorogo berjumlah 6000 dokumen rekam medis.

Tahapan pelaksanaan retensi rekam medis dipisahkan dari rak aktif ke inaktif berdasarkan tanggal terakhir pasien datang berobat, rekam medis diambil dari ruang filing aktif dipindahkan ke ruang inaktif dan disejajarkan. Dalam penjajaran rekam medis inaktif menggunakan sistem straight numerical system, disimpan di rak rekam medis inaktif dan ada juga yang di taruh di dalam kardus. Untuk ketentuan lamanya penyimpanan rekam medis aktif berdasarkan wawancara dengan petugas filing RSU Muhammadiyah Ponorogo sekitar 2 sampai 3 tahun lamanya

2. Tinjauan pelaksanaan retensi dokumen rekam medis di RSU Muhammadiyah Ponorogo

Berdasarkan hasil wawancara yang dilakukan peneliti pada tanggal 11 juni 2019 pada petugas rekam medis terkait tinjauan pelaksanaan retensi dokumen rekam medis bahwa RSU Muhammadiyah Ponorogo Retensi dokumen rekam medis dilakukan sejak tahun 2014 sampai sekarang oleh petugas filling dan semua petugas filling dengan surat penunjukan dari kepala Instalasi Rekam Medis RSU Muhammadiyah
Ponorogo jumlah petugas diruang filling secara keseluruhan ada 10 petugas medis diantaranya 3 yang bertugas di bagian filling 7 petuas instalasi Rekam Medis yang meliputi pelaporan, pengolahan data. Coding. Dikarenakan kurangya petugas di bagian filling maka petugas filling pada saat melaksanakan retensi juga melaksanakan pemilihan nilai guna dan melakukan scanner.

Penyimpanan secara sentralisasi. Ruang filling in aktif tergabung menjadi satu dengan ruang filling aktif, Ruang filling terdapat 2 ruang penyimpanan dokumen rekam medis yang terdiri dari 28 rak kayu untuk dokumen rekam medis aktif dan 10 rak kayu untuk dokumen rekam medis in aktif.

Berdasarkan hasil penelitian di RSU Muhammadiyah Ponorogo sudah memiliki standar operasional prosedur retensi rekam medis. Standar operasional prosedur yang telah dibuat oleh pihak RSU Muhammadiyah Ponorogo ini bertujuan sebagai pedoman dalam melakukan kegiatan retensi oleh petugas rekam medis khususnya petugas filing. SOP retensi rekam medis yang ada di RSU Muhammadiya Ponorogo yaitu:

a. Melakukan inventarisasi berkas rekam medis yang umurnya lebih dari 5 tahun dari kunjungan terakhir.

b. Mengambil berkas rekam medis sesuai nomor RM dari hasil pengumpulan data berkas rekam medis yang lebih dari 5 tahun, tanpa ditukar dengan treacer.

c. Berkas rekam medis yang diambil dari rak penyimpanan, diurutkan mulai nomor terkecil sampai dengan nomor terbesar terakhir

d. Berkas rekam medis yang sudah disusun, disimpan di ruang penyimpanan non aktif sesuai urutan tersebut diatas

e. Apabila ada pasien datang ulang (Her Opname) berkas rekam medis dikeluarkan dari rak 
penyimpanan non aktif menjadi berkas rekam medis aktif.

f. Berkas rekam medis pasien datang ulang tersebut, selanjutnya disimpan di rak penyimpanan berkas rekam medis aktif pada rak penyimpanan terakhir.

\section{PEMBAHASAN}

1. Tinjauan pelaksanaan retensi dokumen rekam medis di RSU Muhammadiyah Ponorogo

Berdasarkan hasil wawancara di Rumah Sakit Umum Muhammadiyah Ponorogo pada tanggal 11 Juni 2019 RSU Muhammadiyah Ponorogo sudah melakukan retensi rekam medis dan pelaksanaan tersebut terakhir tahun 2014, Pada saat ini RSU Muhammadiyah Ponorogo melaksanakan retendi dokumen rekam medis pada tahun 2015 dengan jumlah dokumen rekam medis 60.000 dokumen yang akan diretensi.

Tahapan pelaksanaan retensi rekam medis dipisahkan dari rak aktif ke inaktif berdasarkan tanggal terakhir pasien datang berobat, rekam medis diambil dari ruang filing aktif dipindahkan ke ruang inaktif dan disejajarkan sesuai sistem straight numerical system. Untuk ketentuan lamanya penyimpanan rekam medis aktif berdasarkan wawancara dengan petugas filing RSU Muhammadiyah Ponorogo sekitar 2 sampai 3 tahun lamanya.

Petugas meretensi dokumen rekam medis dalam waktu 1 (satu) bulan dengan jumlah 3000 dokumen rekam medis yang diretensi terdapat 100 dokumen yang tidak bisa di retensi di karenakan dokumen rekam medis rusak/tidak bisa dibaca tanggal terakhir berobat petugas akan memisahkan dokumen rekam medis yang rusak kemudian petugas akan melihat di komputer data kunjungan pasien berobat dan petugas bisa melihat tanggal terakhir pasien berobat.
Dokumen rekam medis yang penting sebelum di retensi terlebih dahulu akan di scant dan data akan di simpan di file. Di RSU Muhammadiyah terdapat form rekam medis yang tidak bisa diretensi meliputi:

a. Surat kelahiran

b. Surat kematian

c. Surat inform consent

d. Surat resum medis pasien

e. Surat tindakan operasi

Pelaksanaan retensi yang dilakukan setiap 5 tahun ini sesuai dengan teori dan SOP yang berlaku di Rumah Sakit Umum Muhammadiyah Ponorogo yang mengatur bahwa retensi dilakukan setiap 5 tahun dari kunjungan terakhir pasien. Hal ini menyebabkan kapasitan penyimpanannya yang lebih sempit dibandingkan dengan jumlah rekam medis yang setiap harinya bertambah sangat banyak. Sehingga harus dilakukan retensi lebih cepat.

2. Menganalisis pelaksanaan retensi dokumen rekam medis di RSU Muhammadiyah Ponorogo

Berdasarkan hasil wawancara pada tanggal 11 juni 2019 jumlah dokumen rekam medis yang diretensi setiap harinya mencapai 100-150 dokumen. Setiap bulan petugas meretensi dokumen sebanyak 3000 dokumen. Dalam ruang fillingyang bertanggung jawab hanya 3 orang petugas dan itupun petugas memiliki tugas pokok sendiri. Sehingga masih banyak dokumen yang menumpuk. Akibatnya dokumen rekam medis yang akan direntensi tidak segera selesai. oleh karena itu diruang fillingdokumen rekam medis menjadi penuh.

Alat yang digunakan untuk melakukan retensi adalah spidol, tali rafia, staples, scanner yang digunakan untuk menscan formulir yang bernilai guna, yang dilakukan setiap hari oleh petugas retensi. hal ini selaras dengan penelitian Devita Saraswati (2015) menyatakan bahwa 
hal yang paling terpenting dalam pelaksanaan retensi adalah penyiapakan alat-alat untuk pelaksanaan retensi seperti spidol, tali rafia, staples, scanneryang digunakan untuk menscan formulir yang bernilai guna, yang dilakukan setiap hari oleh petugas retensi.

Berdasarkan hasil penelitian yang peneliti dapatkan mengenai adanya tinjauan pelaksanaan retensi dokumen rekam medis maka peneliti berpendapat bahwa salah satu lancarnya pelaksanan retensi yaitu penyediaan alat-alat yang akan digunakan untuk pelaksanaan retensi dan pelaksanaan retensi sesui dengan prosedur dan petugas lebih teliti lagi terhadap dokumen yang akan di retensi dengan cara melihat tanggal terakhir berobat dan petugas harus tau lembar apa saja yg tidak boleh diretensi oleh petugas retensi.

\section{KESIMPULAN}

Berdasarkan hasil penelitian yang telah dilakukan tentang Analisa Pelaksanaan Retensi Dokumen Rekam Medis di RSU Muhammadiyah Ponorogo dapat disimpulkan sebagai berikut:

Pelaksanaan retensi di RSU Muhammadiyah Ponorogo ada 3 petugas yang bertanggung jawab terhadap pelaksanaan retensi setiap hari petugas menyelesaikan 100-150 dokumen yang telah di retensi dengan jumlah perbulannya 3000 dokumen rekam medis yang telah diretensi, Petugas bertanggung jawab atas pelaksanaan retensi dan petugas juga memiliki tugas pokok selain melaksanakan retensi dokumen rekam medis.

Petugas pelaksanaan retensi belum pernah mengikuti pelatihan atau kepala rekam medis hanya melakukan pengarahan di ruang filling dan Terdapat kendala pada saat pelaksanan retensi yaitu dokumen yang sulit di baca dan ada ketidak lengakapan formulir data menyebabkan terlalu lama waktu yg dibutuhkan untuk pelaksanaan retensi. Dokumen rekam medis in aktif dan dokumen aktif di jadikan satu dalam ruangan filling sehingga menyulitkan petugas untuk melaksanakan retensi

\section{SARAN}

1. Bagi institusi pendidikan

Hasil penelitian ini diharapakan dapat menjadi tambahan wawasan di institusi pendidikan khususnya di bidang rekam medis

2. Bagi petugas filling

Perlu meningkatkan pelaksanaan retensi dokuemen rekam medis dan perlu hati-hati pada saat pelaksanaan retensi dengan cara meilhat tanggal terakhir pasien berobat dan petugas rekam medis memisahkan antaran ruang rekam medis in aktif dan rekam medis aktif.

3. Bagi kepala rekam medis

Kepala rekam medis memilih atau menunjuk petugas filling untuk pelaksassnaan retensi agar petugas tidak memiliki tugas pokok dan lebih efesien

\section{DAFTAR PUSTAKA}

Azwar, A. 2010. Pengantar Administrasi Kesehatan. Jakarta: Bina Rupa Aksara

Azwar, A. 2010. Pengantar

Administrasi Kesehatan. Jakarta: Bina

Rupa Aksara

Depatemen Kesehatan Republik Indonesia. (2006). Pedoman Penyelenggaraan dan

Prosedur Rekam Medis Rumah Sakit di Indonesia. Jakarta: Depkes RI

Devita saraswati. 2015. Tinjauan Pelaksanaan retensi dokumen rekam medis di bagian filling rumah sakit Bhakti Wira Tamtama Semarang.

Kemenkes RI. 2008. Permenkes No. 269/MENKES/PER/ III/2008 Bab II Pasal 2

tentang rekam medis. Jakarta: Depkes RI 
Kemenkes RI. 2013. Permenkes RI No.55 Tahun 2013 tentang

Penyelenggaraan

Pekerjaan Perekam Medis. Jakarta: Depkes RI

Kemenkes RI. 2014. Permenkes RI No.56 Tahun 2014 tentang Klasifikasi dan

Perizinan Rumah Sakit. Jakarta: Depkes RI

Notoatmodjo, Soekidjo. 2010. Metodelogi Penelitian Kesehatan. Jakarta: Rineka

Cipta

Permenkes No 56. 2014. Pedoman pelaksanaan program jaminann kesehatan nasional

Permenkes No 55. 2013. Jaminan kesehatan

Rustiyanto, E., \& Rahayu, W.A. (2011). Manajemen Filling Dokumen Rekam Medis dan Informasi Kesehatan. Yogyakarta: Politeknik Kesehatan

Rustiyanto, 2012. Etika Profesi Perekam Medis dan Informasi Kesehatan.

Yogyakarta: Graha Ilmu

Sugiyono, 2012. Metodelogi Penelitian Kesehatan. Yogyakarta: Mitra cendekia 